\title{
Ekonomi-Politik Yönleriyle Karşılaştırmalı Roman Analizi: Gazap Üzümleri, Demirciler Çarşısı Cinayeti ve Yusufçuk Yusuf
}

\author{
DR. AZIZZ ŞEKER* - DR. EMRE ÖZCAN**
}

\section{Öz}

Toplumsal gerçekliğin çözümlenmesini, tarihsel-toplumsal dönüşümlerin bireylerde yarattığ1 etkiler üzerinden ele alan romanlar edebiyat sosyolojisinde önemli bir yer tutmaktadır. Bu etkilerin neredeyse tüm boyutlarıyla irdelenmesi, ilgili romanların ve yazarlarının çok daha özgün ve değerli bir konuma yerleşmesine sebep olmaktadır. Tarihsel-toplumsal dönüşümlerin her bir coğrafyada kendine içkin farklı koşullarda açığa çıkması, o romanların evrensel niteliğinden ödün verildiği sonucunu doğurmamaktadır. Her ne kadar coğrafyalar farklı olsa da bu romanların okurda hissettirdiği temel şey, insanların sosyo-ekonomik ve politik yapıyla olan etkileşiminin gücüdür. Bu gücü aktarmak, her zaman için toplumsal yapı ile birey arasındaki belirleyen-belirlenen şeklindeki tek taraflı bir ilişkiden çıkmakla alakalıdır. Ancak ve ancak bu gerçekleştiğinde insanların toplumsal yapı üzerindeki değişim iradesini nasıl ifade ettikleri anlaşılabilmektedir. Bu iradeyi edebiyat sosyolojisinde en güçlü şekilde ortaya çıkaran yazarların başında John Steinbeck ve Yaşar Kemal gelmektedir. Birbirinden oldukça uzak coğrafyalarda benzer temalarda buluşan her iki yazar da üretim ilişkilerindeki dönüşümleri ve bu dönüşümlerin bireyler üzerindeki sonuçlarını, onların değişim iradesine olan inanciyla çevreleyerek vermektedirler. Steinbeck, Gazap Üzümleri'nde Kaliforniya'da kapitalistleşmenin etkilerini Joad ailesi üzerinden ortaya koyarken Yaşar Kemal, Demirciler Çarşısı Cinayeti ve Yusufçuk Yusuf romanlarında Derviş ve Mustafa karakterleriyle aynı yöntemi Çukurova için geçerli kılmaktadır. Toplumsal dönüşüme dair umut ise Peder Casy, Arzuhalci Ali ve Demirci Mustafa üzerinden vurgulanmaktadır.

Tüm bunlardan hareketle bu çalışmada, Steinbeck'in Gazap Üzümleri ile Yaşar Kemal'in Akçasazın A ̆̆aları'nın iki cildini oluşturan Demirciler Çarşısı Cinayeti ve Yusufçuk Yusuf romanları ekonomipolitik yönleriyle karşılaştırılarak incelenmektedir. Bu karşılaştırma, üretim ilişkilerindeki dönüşümlerin toplumsal ve kültürel sonuçlarını ortaya koyarak gerçekleştirilmektedir.

Anahtar Sözcükler: Edebiyat Sosyolojisi, Üretim İlişkileri, Ekonomi-Politik, Gazap Üzümleri, Demirciler Çarşısı Cinayeti, Yusuf̧̧uk Yusuf.

\section{COMPARATIVE NOVEL ANALYSIS WITH ECONOMIC-POLITICAL ASPECTS: GRAPES OF WRATH, DEMIRCILER ÇARŞISI CINAYETİ AND YUSUFÇUK YUSUF}

\footnotetext{
Abstract

* Amasya Üniversitesi, shuaziz@gmail.com, orcid: 0000-0001-5634-0221

** Başkent Üniversitesi, emreozcan8747@gmail.com, orcid: 0000-0002-0877-2457

Gönderilme Tarihi: 18 Ocak 2021 Kabul Tarihi: 6 Şubat 2021
}

Novels that deal with the analysis of social reality through the effects of historical-social transformations on individuals have an important place in the sociology of literature. The examination of 
these effects in almost all dimensions causes the relevant novels and writers to settle in a much more original and valuable position. The emergence of historical-social transformations under inherent and different conditions in each geography does not result in compromising the universal character of those novels. Although the geographies are different, the main thing that these novels make the reader feel is the power of people's interaction with the socio-economic and political structure. Transferring this power is always about leaving a one-sided relationship between the social structure and the individual as determinant-determined. If and only when this happens, how people express their will to change over the social structure can be understood. John Steinbeck and Yaşar Kemal are among the most powerful writers who express this will in the sociology of literature. Meeting with similar themes in geographies quite distant from each other, both authors reveal the transformations in production relations and the consequences of these transformations on individuals by surrounding them with their belief in the will of change. While Steinbeck demonstrates the effects of capitalization in California through the Joad family in the Grapes of Wrath, Yaşar Kemal makes the same method valid for Çukurova with the characters of Derviş and Mustafa in the novels of Demirciler Çarşısı Cinayeti and Yusufçuk Yusuf. The hope for social transformation is emphasized through Father Casy, Petitioner Ali and Hammersmith Mustafa.

Based on all these, this study examines the novels of Demirciler Çarşısı Cinayeti and Yusufçuk Yusuf, which form the two volumes of Yaşar Kemal's Akçasazın Ağaları and Steinbeck's Grapes of Wrath by comparing them with their economic-political aspects. This comparison is made by revealing the social and cultural consequences of transformations in production relations.

Keywords: Sociology of Literature, Production Relations, Economy-Politics, Grapes of Wrath, Demirciler Çarşısı Cinayeti, Yusufçuk Yusuf.

\section{Gİiş̧}

I oplumsal gerçekliklere dayalı edebî metinler günümüzde sınıf, çalışma yaşamı, yoksulluk, sosyal dışlanma, sosyal politika gibi konularla birlikte daha fazla yan yana gelmektedir. Edebi metinlerin içerik olarak bu konular üzerine oturtulması, onların sosyal teorinin önemsediği olgular arasında yer almasını sağlamaktadır. Edebi metinlerden hareketle sosyal teori için, toplumsal bilginin farklı kaynaklarının neler olabileceği, bu kaynakların hangi açıdan ve koşullarla alana nasıl katkı sağlayabileceği, yahut hangi alanların bunun dışında tutulması gerektiği ve bu alanların sınırlılıklarının neler olabileceği önemli sorulardır (Hacısalihoğlu, 2020, s. 231-33). Dolayısıyla edebiyat ve sosyal teori arasındaki işbirliği, insanların varoluşunda ve birlikte sürdürdükleri yaşamın sorgulandığı diğer birçok alanda etkili olabilmektedir (Bauman ve Mazzeo, 2019, s. 119). Bu varoluştan ayrılamayan ekonomi-politik alan da bunun en net tezahürüdür. Bu bağlamda bir örnek vermek gerekirse, İngiltere ilk akla gelen olur. Batılı ülkeler arasında endüstrileşme devrimini ilk başlatan ve en hızlı gerçekleştiren İngiltere olmuştur. Bütün hızına, etkinliğine, başarısına karşın İngiliz toplumunun tarım kültüründen endüstriye geçişi büyük yapısal dengesizliklerle doludur. Bununla ilgili Dickens'in 19. yüzyılın toplumsal çelişkilerini detaylıca yansıttığı, toplumsal kutupların toplumsal panoramasını işleyen romanlarına bakılabilir (Güvenç, 1991, s. 296). Diğer yandan Zola'nın Germinal'i; 1800'lü yılların sonlarına doğru Fransa'nın kuzeyinde maden ocaklarındaki işçilerin çalışma yaşamı ve aileleriyle birlikte içinde yer aldıkları toplumsal koşulları bütün çelişkileriyle görmek adına okunabilecek ekonomik-politik bildirim yüklü bir romandır. Bu düzlemde örnekler çoğaltılabilir. Romanların toplumsal değişmenin çatışmalarını ve etkilerini vermekteki tarihsel başarısı gözetildiğinde edebi metinler içerisinde sınıf, çalışma yaşamı, sosyal problemler ve sosyal politikaya dair birçok konunun yanıtını bulmak mümkündür. Dönüşmekte olan toplumsal yapıda yaşanan 
farklı çelişkileri yansıtan çok sayıda edebi metin olduğu bilinmektedir. Bu sebeple edebi metinler üzerinde araştırmacının amacı doğrultusunda gerçeği en iyi yansıtabilenlerle ilgili bir çerçeve çizilebilir. Bu açıdan edebi metinler içinde roman türünün sosyal analiz nesnesi olarak çok daha tercih edildiği görülmektedir. Bunun gerekçeleri arasında romanin insanlığın tarihinde yer alan dönemlere ayna tutması önemli bir yer kaplamaktadır. Daha yakından bakıldığında aynanın gücü, yazarın toplumsal gerçekliği analiz edebilme becerisi doğrultusunda ayrıntılı şekilde vurgulayabilmesiyle işlev kazanmaktadır.

Öyle ki, insanlığı yakından ilgilendiren sosyo-ekonomik ve tarihsel dönüşüm dönemlerinin geçmişte veya bugünde vücut bulma-

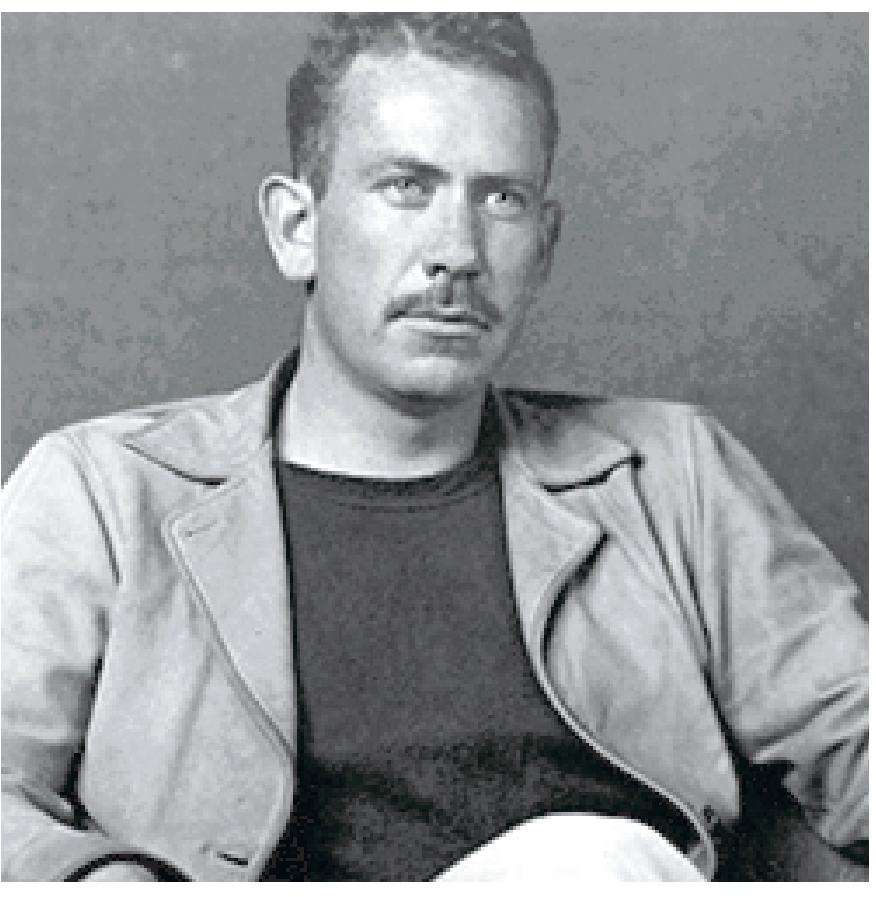

John Steinbeck sında önemli olan bireyin yaşantısını, ele alınan dönem içinde yukarıda da değindiğimiz üzere kendisinden asla bağımsız olmayan tarihsel-toplumsal ve politik gerçekliğine bağlı kalarak yansıtabilmektir. Sonuçta tarih, öznellikler üreten insanların hikâyesidir. Haklı olarak, öznellik üretim süreçleri üzerinden tüm tarihsel süreci okuyabilmek ve anlayabilmek gerekli bir bilgi kaynağıdır. Bunu anlamak, birey ve toplum arasına yerleştirilen dikotomik bağı ortadan kaldırmak demektir. Birey ve toplum arasına konulan ikiliği Tarde'dan (2019) yola çıkarak değerlendirirsek, bireyliklerin içindeki toplumları, toplumların içindeki bireylikleri, arzu ve inanç akışlarının, toplumsallığın tamamına yayıldığını görmezden gelme riskini ortaya çıkaracaktır. O halde bireyi ayrı, toplumu ayrı bir konumda çözümleme hatasına düşmemek gerekmektedir. Bu ilke, romanların toplumsal gerçeklikle olan ilişkisi için de oldukça hayatidir. Roman, ister var olduğu dönemi isterse geçmişi ele alsın, içeriği ve yapısı itibariyle bir öznellik üretimi analizi olmak durumundadır. Meşruiyet sağlayacak bir analiz, tekrar etmek gerekirse, birey ve toplum arasındaki ikiliğin yıkımıyla olanaklıdır. İlk bakışta bireyin konumunu romanlarda nasıl düşünebiliriz? Sorusuna yanıt için özellikle edebiyat sosyolojisi bağlamında Goldmann'ın şu ifadeleri yol gösterici olmaktadır:

“Romanın görünürde sergilediği son derece karmaşık yapı, aslında, insanların her gün içinde yaşadıkları, yozlaşmış bir şekilde, en nitelikliyi, değişim değeri en yüksek olanı bulmak zorunda oldukları yapıdır ve böyle bir toplumda, bütün çabaları direkt olarak kullanım değerine yönelmek olan bireyler doğal olarak yozlaşmış, bir başka deyişle problematik bireyler olarak görülürler" (Goldmann, 2005, s. 27).

Bireyin, onu toplumsallıktan bağımsız olarak düşünmeden roman ögeleri içinde önemli bir sorunsal oluşturduğu burada ortaya çıkmaktadır. Doğaldır ki, bireyin sosyal çevre içindeki durumu, çatışmaları, girmiş olduğu ilişkileri, rolleri, diğer pek çok sosyal olgu etrafındaki konumlanışı roman analizlerinin odaklandığı noktalardır. Yukarıda belirtildiği gibi toplumsal gerçeklik temelinde kurgulanan romanlarda, olay örgüleri arasında sosyo-ekonomik ve politik değişimler belirleyici etmendir. Bu tür romanlar hem toplumsal yapı çözümlemesi hem de romanın sosyolojik doğası hakkında öngörü oluşturur.

John Steinbeck ve Yaşar Kemal'de bunun nesnel anlatımını görmekteyiz. Her iki yazar, romanlarında bunu açılayacak türde konular kaleme almışlardır. Bu bağlamda Steinbeck' in 1930'lu yıllarda Amerika'da geçen Gazap Üzümleri isimli romanı mekânsal çevresi değişmekte olan Oklahoma başta 


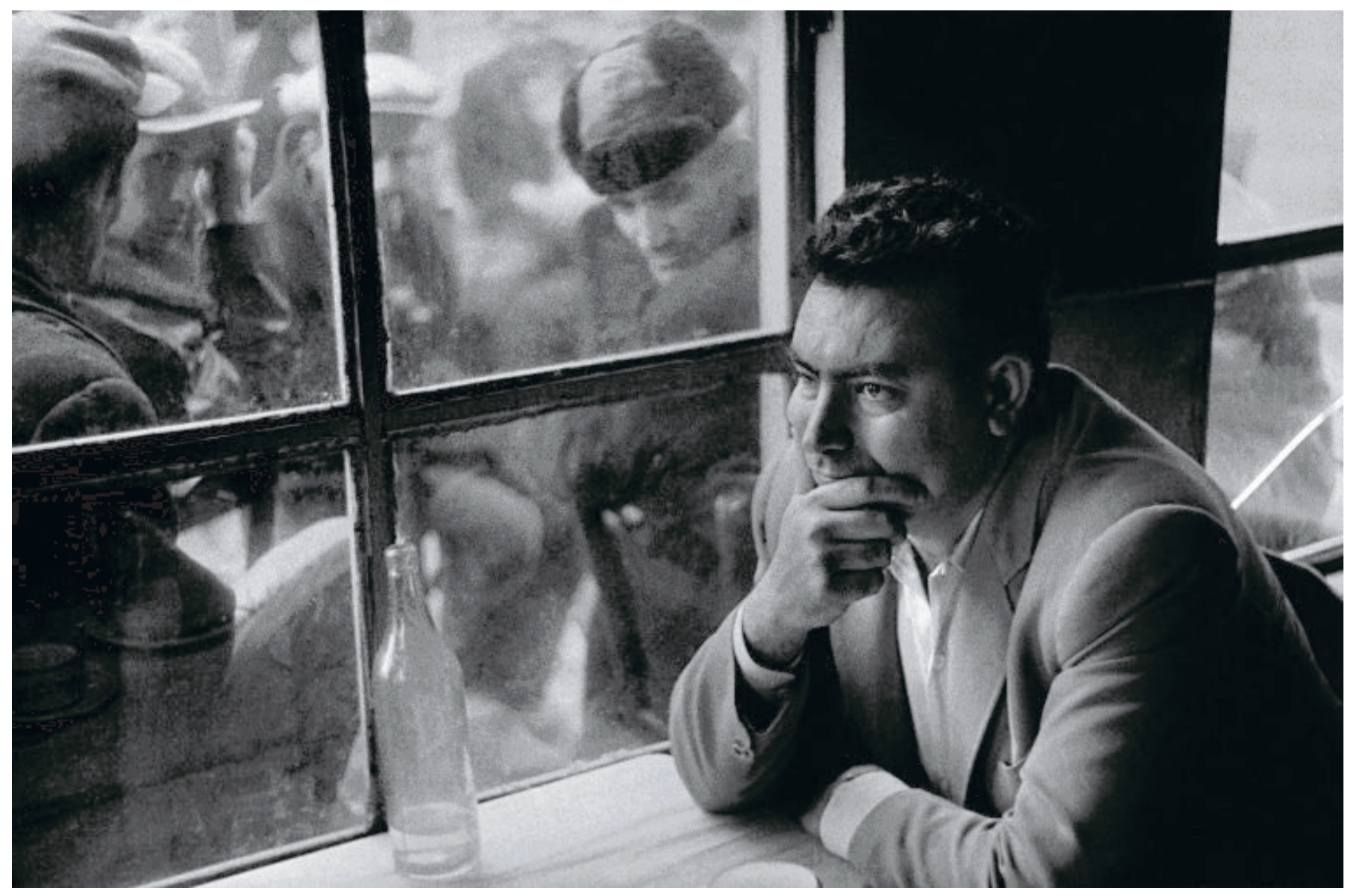

Yașar Kemal

olmak üzere Kaliforniya ve oraya kadar giden yol üzerindeki yerleşimlerde yaşanan sosyal olaylardan oluşmaktadır. Topraklarından koptuktan sonra giderek yoksullaşan bir aile odakta tutularak üretim ilişkilerindeki değişimlerin insanlar üzerinde ortaya çıkardığı sosyal sonuçlar işlenir. Yaşar Kemal'in Akçasazın Ağaları isimli iki cilt olarak yayımlanan Demirciler Çarşısı Cinayeti ve Yusufçuk Yusufromanları ise Türkiye'de Cumhuriyetin kuruluş yıllarından itibaren çok partili sisteme geçişin sosyolojik bir dökümünü içinde taşırlar. Romanlarda, Sarıoğlu aşiretinin lideri Derviş Bey, Çukurova toplumsal yapısı içinde toprak sahibi geleneksel bey karakterinde verilir. Aynı şekilde kan davalısı Akyollu aşiretinin lideri Mustafa Bey de topraklarında insanlar çalıştıran, suç ve cezayı yıllarca kendi topraklarında uygulamış Derviş Bey ile ortak özellikleri bulunan bir bey tipidir. Yeri gelmiş köylülerin topraklarını ele geçirmek için dağlarda besledikleri eşkıyaları düze indirip, köylülerin evlerini bastırıp yakıp yıkmışlardır. Her iki bey, bölgelerinde tarımsal kapitalizmin gelişimiyle değişen sosyal ekonomik politik koşullara yenilerek kendi yalnızlıklarına çekilip tarihteki rollerini yerine getirmişlerdir. Kan davası sonucunda iki aileden onlarca kişinin cinayete kurban gitmesine rağmen ailelerin son kuşak temsilcileri ekonomi politiğin yasalarına karşı gelmeyerek ve ortak işletmeler kurarak sosyal değişime uyum göstermişlerdir. Ayrıca incelenen romanlarda Yaşar Kemal, “yeni yerleşik düzene geçmiş bir toplumun doğmakta olan burjuvazisinin aşiret değerlerini nasıl yıktığını göstermekle kalmayıp, doğal çevreyi de nasıl altüst ettiğini" vurgulamaktadır (Gürsel, 2000, s. 44). Dahası Yaşar Kemal'in birbirinin devamı niteliğindeki iki yapıtı üretim araçları ve üretim ilişkilerinin değişiminin gerekçeleriyle ve sonuçlarıyla aktarılışı yönünden oldukça anlamlı sosyolojik çıkarımlar yapılabilmesini mümkün kılmaktadır. Ekonomik bir deyişle, hızlı değişimlerin yaşandığı 20. yüzyıl, insanın yabancılaşması sorununu gündeme getirmektedir. Akçasazın A ğaları'ndaki iki romanda derebeylik anlayışından kapitalist düzene geçerken nasıl bir toplumsal değişim geçirildiğinin ipuçları verilir. Anlatılan şey, değişimi anlamazdan gelen, ertelemek isteyen derebeylik anlayışının acıklı öyküsüdür (Onaran, 2003, s. 157). 
Bu çalışmada her iki yazarın romanlarının tercih edilmesinin nedeni romanlarının sosyolojik temelini oluşturan ekonomi-politik süreçleri toplumsal gerçekliğe bağlı kalarak ve birey-toplum karşıtlı̆̆ını ortadan kaldırarak işlemelerindeki özgünlügüyle ilişkilidir. Söz konusu romanlarda üretim ilişkilerindeki dönüşümler insanın öznellik üretiminde ne gibi sonuçlar doğurduğunu ortaya koyması bakımından oldukça ilgi çekicidir. Kuşkusuz ki, bir romanın sosyal gerçekliğe bağlı kalmasının en güvenilir yolu bireyin diğer insanlarla kurduğu ilişkilerin tasvirinden geçmektedir. Bunu, kurgu ve roman tekniği bakımından başarabilen romancı hem temelsiz bir politik propagandaya düşmeden dönemin toplumsal ve ekonomik yapısını eserine taşıyacak hem de günümüz romanının bilinçli tercihlerinden biri olan gerçeklikten kopma sorununu aşmış olacaktır (Yılmaz, 2013, s. 22). İki yazar bu doğrultuda roman sosyolojilerine sosyolojik bir imgelem gücü yüklerken, sorunsal olarak ele aldıkları ekonomik politik ögeler açısından da sosyal teori için işlenebilir bir analiz malzemesi ortaya çıarmaktadırlar. Buna ek olarak bir başka ayrıntıya değinmek gerekir. Şöyle ki, Tharaud'un Çukurova Yaşar Kemal Edebiyatının Temelleri isimli çalışmasında, Dağın Öte Yüzüüçlemesini kritik ederken yaptığı, “Dickens, Zola veya Steinbeck'in sosyal sorun romanlarına denk insani var oluşun destansı bir eserini üretmek için türün bütün sınırlarının ötesine geçer" saptamasını Akçasazın A ğaları için de ileri sürmek mümkündür (Tharaud, 2017, s. 47).

\section{GAZAP ÜZÜMLERI İLE DEMİRCILLR ÇARŞISI CINAYETI VE YUSUFÇUK YUSUF'UN EKONOMİ-POLITTIK ANALİİ}

Gazap Üzümleri'nde Oklahoma'da, “1rgatların gidip geldiği yollarda toprağı tekerler öğütüyor,

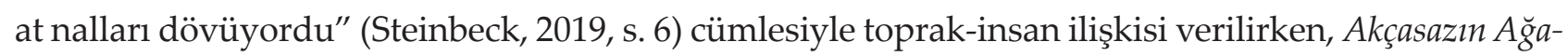
ları romanının ilk cildi Demirciler Çarşısı Cinayeti' nin başlangıcında ise yöredeki tarımsal yapıda olup bitenler betimsel olarak kısaca aktarılır: "Gecede sesler birbirine karışıyor. Gece sesi, kuş sesi, nadas yapan traktörlerin sesi... Ova yıldız yıldız. Mazot kokuları geliyor ta uzaklardan, bataklık, kuru ekin, yanmış çiçek, toz, pıtırak kokularına karışıp" (Kemal, 1998, s. 40). Yapılan alıntılarda, her iki romanın insan-toprak-makine açısından temsil ettikleri gerçekliğin uyuştuğunu söylemek mümkündür. Kendi topraklarında yarıcılık yapanların sonu topraklarını kaybetmek olmuştur. Örneğin, Gazap Üzümleri'nde McAlester hapishanesinde tahrik sonucu kendisini yaralayan birini öldürmesi nedeniyle yatan Tom Joad, şartlı tahliye edilir. Ailesinin yanına gitmek için otostop yaparak bindiği kamyonun şoförü, babasının adını taşıyan Tom Joad'ın karşılaşacağı gerçekliği şimdiden verir: "Yarıcıların durumu berbat," dedi. "Bir traktör geliyor, on aileyi yerinden ediyor. Her yer traktör dolu. Yıka döke gidiyorlar, ortakçıları söküp atıyorlar" (Steinbeck, 2019, s. 13). Diğer taraftan süreçten yararlanmasını bilenler de bulunmaktadır.

Akçasazın A ğaları'nda Mustafa Bey'in oğlu politik ekonominin yasalarına uygun hareket etmektedir: “Memet Ali, eli yüzü yağa bulanmış, Akyollu soyu ne ata bakıyor, ne soya sopa. Bunun derdi traktör. Gece gündüz de tarlada traktörün üstünde, harman makinelerinin, orak makinelerinin yanında, işçilerin arasında ve para gözlü. Gece gündüz de kafası hesaplarla uğraşıyor. Beşe alınca ona satabilir miyim? İşçileri daha ucuza, boğaz tokluğuna nasıl çalıştırırım?" (Kemal, 1998, s. 225-226). Öyle ki, bir seferinde tarlalarında çalıştırdıkları insanları çıkarmak için ev içinde baskı yapar ve ninesinin tepkisine rağmen şunu ifade eder: “Bak baba... Bundan böyle karasabanla, atla öküzle çiftçilik olmaz. Bundan sonra yarıcı olmaz. Bundan sonra... Bir traktör bin insandır. Bir biçerdöver on bin... " (Kemal, 1998, s. 261). Sonuçta Mustafa Bey de farkındadır ki, "çoktandır ovada ortakçılık, yarıcılık bitmiş, topraksız köylüler aralıkta köy köy, çiftlik çiftlik dolaşmaya başlamışlardı" (Kemal, 1998, s. 262). Yazarların, okuru bilgilendirdiği ayrıntıların altını kalınca çizmek gerekir. Steinbeck, romana konu olan olayları ve karakterleri bir roman estetiğiyle vermekle birlikte üst anlatıcı rolüyle değişen 
sürecin sosyolojik değerlendirmesini kendi cümleleriyle yapar. Bu özellik, Yaşar Kemal'de de gözlenen bir üst anlatıcı tutumudur. Her iki yazar sanatın artık bireyi doğrudan değiştirmeyeceğine, ona ancak dünyayı ve yaşamı sorgulama gücü verebileceğine inanmaktadır. Fakat burada da bir değişim söz konusudur; bireye yaşamı sorgulayarak değiştirmeyi öğretmek, ona bu konuda farklı seçenekler sunmak anlamina gelmektedir (Eyigün, 2007, s. 268).

Romanlarla ilgili analize devam edecek olursak, Gazap Üzümleri'nde toprak sahiplerinin, kiracıları topraklarından gönderme nedenleri; arka plandaki bankacılık sektörüne, mali şirketlere, kâra, faize, vergilere, tarımın makineleşmesine dayandırılmaktadır. Yeni toprak sahiplerinin temsilcilerinin ortakçılara-kiracılara anlattıklarına bakmak gerekmektedir: “Ortakçılık sistemi artık yürümez. Traktörü olan bir tek adam, on iki, on dört ailenin yaptığını yapabilir. Ona bir maaş ver, tüm ürünü al. Böyle yapmak zorundayız. Bizim de hoşumuza gitmiyor ama canavar hasta. Bir şey oldu canavara" (Steinbeck, 2019, s. 41). Küçük toprak sahipleri ise yaşanan olumsuzluklara daha kolay yenilirler. Büyük işletmelerin temsilcilerinin aba altından, yoksullaşan toplumsal kesimleri tehdit ettikleri görülür: "Burada kalmanız hırsızlık, kalmak için adam öldürmeniz cinayet sayılır. Canavar insan değildir ama, insanlarına istediğini yaptırabilir" (Steinbeck, 2019, s. 43). Piyasanın dayattıkları ve üretim koşullarındaki değişim doğrultusunda insanlar işçi olarak çalışabilecekleri yerlere doğru göçe zorlanırlar: "Traktörler yolları aşıp tarlalara girdi. Böcek gibi kıpırdayan kocaman yaratıklardı. Böceklerdeki o inanılmaz kuvvet onlarda da vardı" (Steinbeck, 2019, s. 44). Steinbeck'te tanık olunduğu gibi bunlar yaşanırken diğer tarafta kadınları, çocukları ve yaşlıları bekleyen yoksulluk mevcuttur. Aynı düzlem, Yaşar Kemal için de geçerlidir.

Tom Joad boşaltılmış evlerine vardıklarında, orada kalan Muley'i görür. O, Joad'ın ailesiyle ilgili bildiklerini paylaşır: "Şey... pamuk topluyorlardı. Hepsi. Çocuklar ve büyükannen de dâhil. Batıya gidebilmek için para biriktirmeye çalışıyorlar. Bir araba satın alacaklar, yaşamın daha kolay olduğu batı taraflarına gidecekler. Burada hiçbir şey yok. Pamuk toplamak için dönümüne iki dolar para veriyorlar, millet dileniyor hasat işi bulabilmek için" (Steinbeck, 2019, s. 57). Yöredeki ailelerin itildiği toplumsal kıyı ortak bir yazgıdır. Kâr uğruna, topraklarıyla bütünleşmiş halk, anılarıyla birlikte köklerinden koparılır. Yaşar Kemal açısındansa pamuk tarlalarının çokluğu, Çukurova'da modern tarıma geçişin konturlarını içinde taşır. Yusufçuk Yusuf ta Çukurova'daki modern tarıma geçişin emarelerini yazar, okura şu şekilde sunmaya devam eder:

“Masmavi, uzakta aydınlık, yıkanmış açıldı gökyüzü. Çukurova ağzına kadar çiçekle dolmuş. Bucaklardan, kuytulardan turaç sesleri geliyor. Ekinler sararmış, biçiliyor. Traktörler, kamyonlar, biçerdöverler, batoslar, orak makineleri, benzin kokusu doldurmuş ovayı. Boynu uzamış ırgatlar taşlık bir yamaçta, parmaklarında tahta ellikleri ekin biçiyorlar, sıcaktan terleyerek. Bir fabrika çalışıyor Adanada yalımlar içinde. İçinde yüzlerce kişi, yağa batmış. Sıcak taş gibi ağır, soluk aldırmaz, çökmüş. Benzin kokuları çukurlara, derelere birikmiş" (Kemal, 1999, s. 25).

Gazap Üzümleri'nde ihtiyar Tom Joad, geleneksel ailesiyle, aynı isme sahip oğlu Tom Joad'ın gelmesiyle birlikte aldıkları bir kamyonetle yola çıkmayı planlar. Yolculuğa baba, Joad, amca John, anne, büyükanne ve büyükbaba, peder Casy, Noah, Al Joad, Rozaşarn (Rose of Sharon), damat Connie, çocuklar Ruthie ve Winfield toplamda on üç kişi başlanır. Joad ailesi Oklahoma'ya bağlı Sallisaw'dan yolculuğa çıktıkları sırada eski, hiçbir şeye yaramayacak eşyalarını yok pahasına satarlar: koşum takımları, çekçek arabaları, at arabaları, tohum makineleri, oraklar, atlar, el sabanları gibi (Steinbeck, 2019, s. 105). Aile, Kaliforniya'ya doğru yeni baştan başlamanın hayaliyle hareket eder. Gazetelere verilen, "Kaliforniya'da çalıştırmak üzere işçi arıyoruz" ilanlarının yanı sıra el ilanları binlerce insanı cezp etmektedir. Şüphesiz sermaye, insan-toprak ilişkilerini değiştirirken insanların kendi ara- 
larındaki ilişkilerine de etki etmektedir. Eski geleneksel sosyal statüler adeta yerle bir olmuştur. Örneğin büyükbaba, resmi olarak ailenin başı sayılmasına rağmen yalnızca işlevsiz bir söz hakkıyla sınırlanmıştır. Yalnızca anne, verdiği mücadele ölçüsünde aile üyeleri üzerinde otorite figürü olarak varlığını hissettirmektedir. Ev içi işleri saymazsak, bulunabilecek işlerde kadın erkek ayırımı gözetilmeden çalışılmaktadır; hatta çocuklar bile tüm güçleriyle işlerin bir tarafından tutmaktadır. Ekonomik faktörlerin etkisiyle aile içi hiyerarşi çok hızlı parçalanma yaşamaktadır. Çukurova'ya döndüğümüzdeyse, aile hiyerarşisinin yıkımı tarımsal kapitalizmle birlikte bu kadar kökten olmamıştı. Türkiye'de o tarihsel kesitte belli bir bölgeye odaklanıldığından bütün toplumsal kurumlar büyük oranda etkilenmemişti. Ancak bölgedeki değişimin boyutları ölçüsünde insan ilişkileri değişmiştir. Kadınlar ve çocuklar, Yaşar Kemal'in romanlarında daha arka plandadır. Erkeklerin ortasında olduğu patriyarkaya dayalı sosyal ilişkiler, toplumsal yaşamda yine erkeklerin belirlediği politikanın kurallarıyla ekonomik ara yüzde varlığını duyumsatmaktaydı. Ortaya çıkan sonuç, üretim ilişkilerinin bir toplumsal cinsiyet yapılanması bağlamında anlaşılabileceği gerçeğini ise yeniden anımsatmaktadir (Connell, 2016, s. 159).

Teknolojide temel üretim araçlarından biri olan traktörde cisimleşen değişim Gazap Üzümleri’nde şöyle sunulur: “Tek kıpırtı oluklu saçtan yapılmış, gümüş gibi parlayan traktör barakalarıydı. Onlar da madenle, benzinle, yağla, toprağa dalıp çıkan dişlileriyle canlıydılar. Işıkları yanıyordu. Traktör için gece diye, gündüz diye bir şey yoktu çünkü" (Steinbeck, 2019, s. 141). Demirciler Çarşısı Cinayeti'ndeyse traktörün insan eliyle edindiği zaferin yanında köylülerin bir kısmının mücadeleden vazgeçecek gibi görünmemesine karşın, ağaların hükmü onlardan çok daha baskın olur. Şöyle ki:

“Her yıl kuruyan Akçasaza köylüler, Ağalar üşüştüler, Akçasaz toprağını yağma ettiler.

Bentler yaptılar, kanallar açtılar. Köylüler Akçasazdan tarla kazandılar, ama kazandıkları tarlalar ellerinde kalmadı, çeltikçi yeni yetme Ağalara kaptırdılar. Akçasaz bir dönüm toprağı olmayan nice adamları büyük çiftlik sahibi etti, zengin, milyoner etti. Fabrika sahibi etti. Akçasazdan yetişen Ağalar politikaya atılıp bir süre koca bir memleketin kaderine hükmedenlerin arasına katılıp, en olumsuz, en korkunç rolleri oynadılar"' (Kemal, 1998, s. 123).

Egemen ekonomi-politik inşaya eleştirel yaklaşan Yaşar Kemal, “topraksız insan, sürüsüz çobandan beter olur" diyerek köylülerin yaşadıklarını acı bir şekilde özetler (Kemal, 1998, s. 144). Ortaya çıkan yeni ağalar, topraklarını bir yandan genişletmeyi kanun dışı yollarla başarırken, diğer yandan ticarette paradan başka hiçbir şeye bağlanılmayacağının bilinciyle davranmaktadırlar (Kemal, 1998, s. 150). Elbette, toprak-insan ilişkisi tarihsel bir ilişkidir; canlı ve yaşamsaldır. Bu ilişki, traktörle veya başka bir üretim aracıyla ikame edildiğinde, derin bir manevi huzursuzluk ikliminde, geleneksel/mekanik ilişkileri yaşayan insanların sosyal yaşamları sarsılabilmektedir. Aile refahını koruyan, onları yaşananlara karşı güçlendiren geçiş mekanizmaları ya da bir takım sosyal destek içerikli tampon kurumlar olmadığında ise mülksüzleşmiş/topraksızlaşmış, düzenli geliri olmayan yoksul kitlelerin çoğalmasına neden olunur. Bu süreçte özgürlük olgusu kapitalist üretim ilişkilerinde para sahibi olmakla ilişkilidir. Amerika'da veya Çukurova'da tarımsal modernleşmenin iradesini elinde bulunduranlar için tartışılabilir bir yoksulluk gerçekliği, topraklarından ayrılıp verimsiz işlere yönelerek özgürlüğünü kaybedenler yönünden doğrulanmış bir deneyimdir. Öyle ki Gazap Üzümleri'nde, “arkalarında bıraktıkları dehşetten kaçan insanların başına garip garip şeyler gelir. Kimi çok acı ve zalim... ama kimi de öyle güzel ki, inançlar tekrar tutuşur, sonsuza dek dayanır" (Steinbeck, 2019, s. 149). Ancak sonu olmayan acı bir yaşam deneyimiyle aile, yolda önce büyükbabayı kaybeder. $\mathrm{O}$ an bulundukları eyalette cenaze masraflarından dolayı paraları yeterli değildir. Sorun yaşamamak için cenaze, sessizce yol kenarına gömülür. Yolda konaklanan yerlerde karşılaşılan, benzer sosyal prob- 
lemleri yaşayan insanlarla dayanışma gösterilerek ekmeğe ulaşılmaya çalışılır. Çukurova'da da insanlar, adeta "bir ekmeğin kölesi" haline getirilmiştir.

Şüphesiz ki, Gazap Üzümleri ile Demirciler Çarşısı Cinayeti ve Yusufçuk Yusuf romanlarında toplumların karşılaştığı üretim ilişkilerindeki dönüşümler ve romanların dayandığı insan-toplum gerçekliği, sosyolojik değerlendirme için önemli konulardır. Farklı toplumsal-kültürel coğrafyalarda vücut bulan romanlarda, değişen ekonomi-politik yapının yoksul insan kitlelerini çoğalttığı görülmektedir. O halde romanlardan hareketle, Bauman'ın sosyolojik okuması temelinde bir karşılaştırma yapıldığında, ekonomik ilerlemenin kenar oyuncusu olan atık insanların ortaya çıkışını, tümüyle teknik, gayrişahsi bir olgu olarak kabul etmek gerekir. Bu dramın başlıca aktörleri, yani "ticari koşullar", "pazar talepleri", "rekabet baskısı", "verimlilik" ya da "iş performansı", bir adları ve adresleri olan gerçek insanlarla her türlü bağlantıyı görmezden gelmeye, onların niyetlerini, iradelerini, aldıkları kararları gizlemeye ya da yadsımaya yarayan tanımlamalardır. Sonuçta sosyal konumlarını kaybeden, hayatta kalmak için ürkütücü bir mücadele içinde olan insanların Czarnowski'nin deyimiyle “değer kaybetmiş bireyler" oldukları sosyal bir gerçekliktir (Bauman, 2018, s. 54-55).

Steinbeck'e göre, “büyük arazi sahipleri değişikliği seziyor, tedirginleşiyor, ama nasıl bir değişiklik olacağını hiç anlamıyorlar. Büyük mülk sahipleri önlerine ne çıarsa ona yükleniyor. Hükümet yetkilerinin genişletilmesine, işçi dayanışmasının güçlenmesine, yeni vergilere, yeni planlara... Ama bilmedikleri bir şey var. Bunların hiçbiri sebep değil, hepsi sonuç" (Steinbeck, 2019, s. 184). Bu dinamik ögeler, milyonlarca kişiyi etkilemektedir. Konaklanan yerlerde babanın değerlendirmesine bakmak yeterlidir: “İnsanın evinden, yurdundan kopup yollara düşmesi bombok bir iş. Hele bizim gibi kendi toprağ1 olanlar. Biz böyle göçebe değildik. Traktörler gelip bizi söküp atana kadar çiftliklerimiz vardı bizim" (Steinbeck, 2019, s. 230-231). Tek tek mülkiyetlerinden kopan ailelerin çokluğu, Amerika'da makro bir değişimin çıtılarını imler. Dönüşüm, Çukurova'daki değişimin bir aşama üstüdür. Çukurova'da öteden beri toprak mülkiyetinin büyük çoğunluğu ağaların elindedir. Ağaların, beylerin konaklarında ve tarlalarında ortakçı kadınlar çalışmaktadır. Yanaşmalar, yarıcılar ve köylüler boğaz tokluğuna aşiretlere çalışırken, büyük toprak sahipleri çeltik ekimi yapmakta ve pamukla uğraşmaktadırlar. Bankalar da ağalara ve beylere kredi aktarmaktadır. Aileler, makineli tarımdan önce ağaların çiftliklerinde onların denetim ve gözetimi altındayken, çiftliklerin modernize olmasıyla ağalar, çalıştırmak istemedikleri insanları kapının önüne koymaktadır. Böylece çalışmak amacıyla şehirlerin büyük fabrikalarına doğru hareketlilik başlamaktadır. Yaşar Kemal'de toprağa bağlı üretim ilişkileri, Derviş ve Mustafa gibi iki karakter temelinde verilirken yeni üretim ilişkilerinde feodal değerler değişmiş, kâr ve para kazanma hırsı her şeyin üzerine çıkmıştır. Kan davalı olmakla bir yana her iki aşiret sosyal bakım ve korumaya geldiğinde çalışanlarını doyurmaya çalışsa dahi zamanla bu insanlar yerlerinden edilmektedir. Bu noktada yaşanan bir patronaj ilişkisinden söz etmek gerekir. Eşit olmayan ilişkiden doğmakla birlikte bey/ağa çeşitli ekonomik hizmetler, siyasal itaat, şeref ve prestij karşılığında köylünün geçimini, özellikle de sosyal güvenliğinin sorumluluğunu üstlenmektedir (Kiray, 1999a, s. 273).

Muzaffer, değişen süreç hakkında Derviş Bey'e bilgi verdiğinde, karşılığında babası "milletin, şu fakir milletin toprağını çalmak için Mahirle bir hırsızlık çetesi kuramam. Zaten hiçbir işte, en küçüğünden en büyüğüne kadar, hiçbir şeyde onunla birleşemem. Son sözüm budur. Kusura kalma oğlum, ben bu haltları yiyemem" der (Kemal, 1999, s. 61). Ne var ki, aynı kişi kendisiyle dalga geçen bir deliyi, yani Deli Hacı'yı öldürtmek uğruna bir cinayet için kullandığı Mahmut'un oğlu Yusuf'u da hiç düşünmeden katil yapacaktır. Bir çocuğa cinayet işletecek, sonra çocuk yakalanıp konuşmasın diye kendisi çocuğu öldürecektir. Feodal onur, cinayet işleyecek gururla madalyonun iki yüzü gibidir. Öte yandan Gazap Üzümleri'ndeki toplumsal, kültürel farklılıklar ve gelenekler bu anlamda 
bey/ağa ile köylü ilişkisi konusunda bir toplumsal modele sahip değildir.

Gazap Üzümleri'ne dönecek olursak, aile yolda büyükanneyi de kaybeder. Göç eden insanların yol boyunca maruz kaldıkları davranışlar, daima sosyal dışlanma ve aşağılanma olur. Büyükanne, Barstow'da ailenin parası olmadığı için belediye tarafından toprağa verilir. Noah, aileyi terk eder. Kaliforniya'ya vardıklarında beklediği şeyleri göremeyen damat Connie, hamile eşi Rose of Sharon'u ailesiyle bir başına bırakıp gider. Bulundukları kampın ateşe verileceğini öğrenen aileyle yolculuk eden Peder Casy ise bir şerif yardımcısını yaralayan Tom'un yerine olayı kabullenir ve içeri alınır. Tüm bunların cereyan ettiği sırada Kaliforniya rüyasına inanan insanların oluşturduğu kalabalık artarak sürer. Yazarın ifadesiyle:

“Geriden yenileri geliyordu. Koca otoyolları dolduruyordu taşınıp duran insanlar. Orta ve güneybatı kesimlerinde basit bir tarım toplumu yaşıyordu eskiden. Sanayi onları değiştirmemiş, tarımlarına makine girmemiş, özel kişilerin elinde makinenin ne kadar güçlü ve ne kadar tehlikeli olabildiğini anlamaya fırsat bulamamışlardı. Sanayinin çelişkileriyle içiçe büyümemişti o insanlar. Sanayi hayatının gülünçlüklerine karşı duyuları hâlâ keskindi. Sonra birdenbire makineler onları dışarı atmış, onlar da kendilerini otoyollarda bulmuşlard1" (Steinbeck, 2019, s. 346).

Kaçınılmaz olarak, bunun toplumsal kırılmaları oldukça derindir. Endüstrileşmenin, tarımdaki kapitalistleşmenin Kaliforniya'daki gücüyle gelişen ekonomik eksenli göç neticesinde “barbarlaşan” yepyeni bir kitle meydana gelmiştir. Bu kitlenin adı net olarak konulmasa bile kapitalizmden pay isteyen kişiler olduğu açıktı: “Gruplar halinde yersiz yurtsuzlar, evsiz barksızlar, katılaşmış, hırslı, tehlikeli insanlar. Kaliforniyalıların istediği pek çok şey vardı. Biriktirmek istiyor, sosyal başarı istiyor, eğlence istiyor, lüks istiyor, garip bir bankacılık güvencesi istiyorlardı. Yeni barbarlar ise yalnızca iki şey istiyordu. Toprak ve yiyecek" (Steinbeck, 2019, s. 287). Çukurova'nın yeni ăgaları da buna benzer isteklerle epey yol almışlardı. Eskiden Arap atlarına binen yeni ağalar, artık Fordları ve Mercedesleri kullanma arzusundaydı. Fayton çağı geçmiş, otomobil başlamıştı (Kemal, 1998, s. 298). Derviş Bey'in Tarsus Amerikan Kolej'inde okuyan diğer oğlu Ceyhun'un babasına aktardıkları, yaşanan değişimin ekonomi-politik gerekliliğini net bir şekilde göstermektedir: "Her işin başı ekonomidir. İspat edildi ki çağımızda savaşların, tarihin, her bir varlığın başı sonu ekonomiye bağlıdır. Bugünkü dünyayı soylar, milletler, liderler değil, ekonomi yapıyor. Dünya artık öküzün boynuzunda değil, peygamberin kelamında değil, Allah'ın ayetinde değil. Oğuzun geleneğinde değil, ekonominin sırtında duruyor" (Kemal, 1999, s. 67-68). Söz konusu sosyal-ekonomik durum, sosyolojik olarak ele alındığında denebilir ki, romanda feodalizmin yerine kapitalizmin geçişi anlatılırken güç ilişkilerinin sürekli değiştiği, başta ekonomik ve politik bakımdan güçlü olan Beylerin giderek zayıfladığı yeni Ağaların giderek güçlendiği, bu süreçte ise çökmeğe yazgılı feodal yapıyı koruma olanağı olmadığı ortaya çıkar (Moran, 1999, s.124).

Gazap Üzümleri'ne baktı̆̆ımızda aile, Hoorverville denilen sosyal yardım ve sosyal hizmetlerin sunumunun pek gelişmemiş olduğu komitelerin yönettiği devlet kamplarında konaklar. Aile, iş bulamayınca hep göç etmek zorunda kalır. Ailenin huzursuzluğu, binlerce insanın açlı̆̆ı ve insanı ürküten bir toplumsal atmosfer karşısında baba, bir şeyler değiştiğini sezmektedir: "Ne olduğunu bilmiyorum. Belki sağ kalıp göremeyiz. Ama değişiyor. Bir tedirginlik, sabırsızlık var. İnsan hiçbir şey anlayamıyor... korkuyor" (Steinbeck, 2019, s. 422). Çukurova ağalarından Derviş Bey, sosyo-ekonomik konumu iyi olsa bile değişim karşısında benzer duygulara sahiptir: Ona göre de, "Neydi bu değişen, yok olan, giden?" (Kemal, 1999, s. 240). Her iki koşulda pasif bir tepkiselliğe dönüşen bu psikososyal öznelliği, arka planda yer alan toplumsal değişme süreçleriyle ilişkili olarak ele almak mümkündür: Farklı toplumsal yapılarda gözlemlenen şey, kendisini oluşturan kurumların karşlıklı 
insan ilişkileri düzeni ve değerleri içerisinde üyelerine mutlaka bir güvenlik mekanizması sağladığıdır. Ancak toplumun üyelerinin toplumsal yapının kendisine özel bir güvenlik sağladığını genellikle hissetmediği görülür. Çoğu kez, toplumsal yapıda değişme süreci epey ilerledikten sonra, insanlar yeni düzende bir şeyin eksik kaldığını hissederler. Bu eksik kalan şey, yani güvenlik işte bu psikososyal sorgulamaların nedeni olagelir (Kıray, 1999b, s. 73). Romanlarda geçen toplumsal yap1larda; feodal (geleneksel/mekanik) ekonomik sosyal ilişkilerde aile, topluluk, toprak ilişkisi, birincil ilişkiler, sosyal sorumluluk aslında bu sonucun ortaya çıkmasını geciktirici olmakla birlikte sosyal değişim yeni ilişki modellerini zorunlu tutmaktadır.

Gazap Üzümleri'ne dönersek, buldukları işlerdeki düşük ücret ve kötü barınma koşulları altında Tom, son gittikleri yerde işçi lideri olarak Peder Casy'i görür. Grev elebaşılığ1 yaptığından Casy, o akşam öldürülür. Tom da buna karşın bir başkasını öldürür, ama yaralanır ve artık gizlenerek yaşamak durumunda kalır. Romanın sonunda kaybolur gider.

Ailenin pamuk işçiliği yaptıkları esnada kaldıkları vagonda Rose of Sharon ölü doğum yapar. Yağmurların artmasıyla ortaya çıkan sel baskını, ailenin yakınlardaki bir ambara yerleşmesine neden olur. Aile, orada aç bir çocuk ile hasta haldeki babasına rastlar. Rose of Sharon'un değer yargılarını bir yana bırakarak hasta adama süt vermesi, romanda geride kalan bir yaşam mücadelesinin ilk belirtisi olur. Önlerinde, geçirecekleri işsiz ve hasatsı uzun bir zaman onları beklerken.

Diğer yandan Yusufçuk Yusuf'ta roman kahramanları arasında yer alan, "aşiret köylüsünün sömürülmesine de, Beyler uğruna canından olmasına da isyan eden” Arzuhalci Ali Efendi'nin başına gelenlerin benzeridir aslında Peder Casy'nin başına gelenler (Moran, 1999, s. 121). Ali Efendi, ağaların halkı sömürmesinden söz ettiğinden dolayı karakola alınır. Onun savaş düşmanı, servet karşıtı, toprak reformu taraftarı, vatan haini ilan edilmesi için miting düzenlenir ve linç edilmekten bir köye sığınarak son anda kurtulur. Mestan gibi Süleyman Aslansoypençe'yi öldüren, sadece bir karış toprak için mücadele edenler de vardır. Bunun üzerine Mestan'ın yakınları vatan haini, din düşmanı ilan edilerek kasaba çarşısında eziyet ettirilerek elleri kelepçeli gezdirilir (Kemal, 1999, s. 203). Yoksul Tellal da aşağılanınca Kurtboğa Ağa'yı öldürür. Mestan, Gazap Üzümleri'nde haksızlığa karşı duruş sergileyen Tom'u anımsatır. Yaşar Kemal'in romanlarında yoksulların amacı Akaçasaz'ın bataklığını kurutup bir parça toprak sahibi olma mücadelesine dönüşürken, Steinbeck'te ailelerin umudu Kaliforniya'nın mısır ve pamuk dolu tarlalarında işçi olup, oralara yerleşmeye dönük gelişir. Her iki romanda iyi bir gelecek ideali ve umut baskın inanç şekilleridir. Ancak her ikisi de gerçekleşmez. Ağalar, yasanın etrafından dolaşarak çeşitli usulsüzlüklerle toprakları mülkleştirirken, Kaliforniya'daki sermayedarlar boğaz tokluğuna aileleri sömürmenin yollarını çoktan keşfetmişlerdir. Politik açıdan bakıldığında, Türkiye gerçekliğine konu olmuş şu meseleyi de anımsatmak gerekir: toprak reformu. Toprak reformu konuşulduğunda Yeni Ağa Mahir'in bakışı şöyledir: “Toprak dağıtımı yapacağına yüz bin, iki yüz bin dönümlük çiftlikler kurdur. O zaman gör memleket nasıl kalkınır. Fabrikalar kur. Köylü de fabrikalarda işçi olsun. İşçi olunca?.. Bu daha tehlikeli. Bir memleketin çoğunluğu işçi olunca, o zaman yandın işte. İşçiler birer beladır memleketin başına. İçinden çıkılmaz iş..." (Kemal, 1999, s. 435).

Yirminci yüzyılda Çukurova'da tarımsal kapitalist dönüşüm sürecinde sınıfların ve statü gruplarının değişen konumlarını Yaşar Kemal'in edebî eserleri açısından inceleyen ekonomik politik bir değerlendirmeye genel hatlarıyla eğildiğimizde, farklı sınıfların ve statü gruplarının dönüşümlerinin karşılıklı olarak ele alındığını görmekteyiz: Eski ağalar olarak nitelendirilen eski toprak sahipleri feodal bir tutkuyla ve ataerkil geleneksel toplumun değerleriyle "sosyal onur" tanımlarına bağl1lıklarından ötürü yeni sermaye birikim sürecinin gerekliliklerini yerine getiremezler. Bir sonraki kuşak entegrasyon konusunda daha başarılıdır. Babalarının bu nedenle reddedilmesi ve topraklarının satışı 
için yeni ağa tiplerinin seferber olması, tek kaygısı ve amacı kâr maksimizasyonu olan yeni bir tür tarım kapitalist sınıfının daha belirgin hale gelmesi sonucunda etkili olmuştur. Toplumsal çözümleme açısından buradaki önemli nokta, dönüşümün eski toprak sahiplerinin aşiret üyelerini ve topraklarında çalışanları etkilemesidir. Doğal olarak eski yapı tasfiye olurken ekonomik koşulları kötü insanların sosyal ağlarının parçalanması veya dönüşmesi; göç eden, iş arayan, şehirlerde fabrikalara sürüklenen toplumsal kesimlerin ortaya çıkış gerekçelerini içinde barındırmaktadır (Gürel, 2019, s. 219). Değişimin büyük oranda Çukurova'nın siyasal yapısına yansıyışı ise birtakım yeni güçlerin, tarım kapitalistlerinin doğması biçiminde olmuştur. Kasaba, kent, derken devletin asker-sivil bürokrat kadrolarıyla bütünleşerek yönetimde her gün biraz daha ağırlığını hissettiren yeni güçler, anlayışlar, politik tutumlar gelişmiştir (Şahin, 2013, s. 92).

Ne var ki, sermayenin kâr hırsı karşısında ortaya çıkan sefalet manzaralarına, açlığa, adil olmayan koşullara tepki veren bir sosyal kesim de hep var olmaktadır. Bu anlamda örneğin her iki romanda da Arzuhalci Aile ile benzer düşüncelere sahip Demirci Mustafa ile Peder Casy, savundukları değerler itibarıyla sosyal adalet yanlısı, eşitlikçi ve sömürüye karşı duran tiplerdir. Fakat ikisi de öldürülür. Yüzler değişir, toplumlar değişir, ancak ölümlerin arkasındaki hayatlar benzerdir. Zulme ve onursuzluğa karşı gelen bu insanların, Çukurova'da yeni ağaların, Kaliforniya'daysa sermayedarların, tarım işletmesi sahiplerinin kiralıkları tarafından vurulmaları ortak kaderleridir. Bir yerde kızıl tahrikçi olarak nitelendirilenler diğer yerde Moskof diyerek ötekileştirilirler. Kaliforniya'da büyük toprak sahiplerinden beslenen Şerif, Çukurova'da ağaların yönlendirdiği kolluk güçleri olabilmektedir. Yine toprak sahipleri, yasa tanımaz hâl aldıklarında tuttukları adamlara; genelde eski eşkıyalara kolaylıkla cinayet işletebilmektedirler. Benzer cezalandırma sisteminde şerifler, karakol çavuşları veya komutanlar yerel politik aktörlerin kullandıkları araçlar arasında yer alırlar.

İncelenen romanlar gösteriyor ki, edebî metinler, sosyal teoriye tüm imkânlarıyla, kuşaktan kuşağa aktardıkları birikimleri ve kapsayıcı etkileşimleriyle gözardı edilemeyecek ölçüde zengin bir tartışma alanı sunmaktadır. Bununla birlikte sanat ve sosyal teori ilişkisi bağlamında çalışma yaşamı, yoksulluk, sınıfa ilişkin çalışmalar, yönteme ilişkin derinlemesine tartışmalardan yoksun bir izlenim vermektedir. Böylece edebiyat ve edebi metinler, bir yandan üretiminin niteliği ve koşulları nedeniyle birlikte çalışılmasından sakınılan bir alan iken, bu şekliyle yaklaşıldığında da üretiminin niteliği ve koşullarının görmezden gelindiği bir inceleme alanına dönüşebilmektedir (Hacısalihoğlu, 2020, s. 232-237). Buna rağmen, birçok formda edebiyat ile politika arasındaki ilişkinin birbirinin etkileşim sahalarına nüfuz eden ve birbirini tehdit eden bir çerçevede geliştiğini gözlemlemek mümkündür. Yazarın içinde yer aldığı toplumsal gelişmelere bağlı bir kişilik olarak şekillendiği gerçeği dikkate alındığında, aslında her türden romanın bir biçimde belli politik duruşu yansıttığı gibi oldukça geniş bir önermeye ulaşmış oluruz (Aslan, 2011, s. 176). Ayrıca varoluşla ilgili hakikati dile getiren, insan ve toplum gerçekliğini işleyen romanların kalıcı oldukları tezi her iki yazarın romanlarının da hak ettikleri bir nitelemedir (Fromm, 1995, s. 86). Bu bağlamda denebilir ki, Steinbeck ve Yaşar Kemal'in hemen hemen aynı tarih dilimini, farklı toplumlar açısından konu aldıkları romanları düşünüldüğünde, sosyal teori için yoksulluk, çalışma koşulları, sosyal dışlanma, sınıfsal ilişkiler, toplumsal eşitsizlikler, sosyal değişim, işsizlik vb. konularda ekonomik politik yönleriyle geniş bir okuma alanı ortaya çıkardıklarını ileri sürmek mümkündür.

\section{SONUÇ}

Yapısal olarak bakıldığında, ekonomik-politik yönlerden iki roman karşılaştırmasıyla sınırlı olduğu ifade edilebilecek olan bu çalışma, ekonomideki evrensel dönüşümün farklı coğrafyalarda yaşayan insanlar için benzer sosyal sonuçlar ortaya çıkardığına dair edebiyat üzerinden eleştirel bir 
okuma yapma olanağı sunmaktadır. Toplumsal bir kurum olarak ekonomi büyük ölçüde sosyal değişmeyi başlatırken, roman türünün de çoğu zaman sosyal bilimcilerin eksikliğini hissettiği bu konularda, yeterli olmamakla beraber sosyal analiz için gerekli verileri içerdiği görülmektedir.

Yukarıda incelenen romanlarda, topraklarından koparılmak zorunda bırakıldıklarında mekânsal açıdan dişlanan yoksullar, kendi dinamikleriyle sanayileşen bir ABD ile geç sanayileşmekte olan Anadolu'nun Çukurova bölgesiyle ele alındığında sosyal sorun olarak toplumsal değişim süreçlerinin anlamlandırılmasına yeni kavramsallaştırma yolları açarlar. Ayrıca ne denli ironiktir ki, Amerika'da kendi koşullarında ortaya çıkan toplumsal yapının değişimi, Çukurova'da Amerika'dan getirilen makinelerin/traktörlerin kullanımıyla hızlanır. Dış faktörün etkisi bir yana etkileşimin karşılıklı olduğu düşünüldüğünde, Çukurova yerelinin sosyo-politik yönüyle evrensel ekonomik süreçlere uyum sağladığı açıktır. Başka bir deyişle, Akçasazın A ̆̆aları nehir romanının iki cildini oluşturan Demirciler Çarşısı Cinayeti ve Yusufçuk Yusuf, bir kasaba ve etrafında geçmiş olmasına karşın en az Gazap Üzümleri kadar makro değişim koşullarını analiz edebilecek sosyolojik bir birikim taşır. Çukurova'da iş adamları büyürken gelen modern bir dünya mıdır, yoksa emek-sermaye çelişkisinin gömlek değiştirmiş hali midir? Elbette soruda geçen iki önerme de ekonomik-politik değişimle ilgili önemli ipuçları taşıdıkları için doğrudur. Nasıl edinildiğine bakılmaksızın "mülkiyet hakkına saygı" ise bu maceranın insani yönünün kritik edilen ögesi olur. Diğer yandan Joad ailesi ile Derviş ve Mustafa Bey'ler, kan davası bir yana yaşadıkları toplumda Homeros'tan beri duymaya alışkın olduğumuz sembolik anlatımla, yani bereketli topraklar üzerinde yeni sermaye gruplarının davranışlarına paralel yoksullaşan köylüler, yarıcılar, ortakçılar ile tarihteki yerlerini alırlar. Bu anlamda romanlarda, olayların geçtiği tarihsel ve toplumsal döneme ilişkin genişçe yer verildiğini söylemek mümkündür.

Her iki yazarın başarısı, toplumsal yapıdaki ekonomik-politik değişimi tarihsel bir durum gibi yansıtmalarındaki yetkinliklerinden ileri gelir. Görüldüğü gibi John Steinbeck ve Yaşar Kemal, bu tarihsel durumu çelişkileriyle işlerken, tutarlı bir estetikle sergilerler. Endüstriyel kapitalizme geçiş, sosyal sınıflar arasındaki uçurumu derinleştirirken insan toprak ilişkisinin değişimi, sömürünün niteliği, yoksulluk, sosyal dişlanma, mülksüzleşme adeta yaşanan toplumsal gerçekliğin adı olur. Bu meyanda ekonomi-politik doğalarının örtüştüğü romanlarda ekolojik dönüşüm de işlenir. Gazap Üzümleri'ndeki mısır ve pamuk tarlaları, Demirciler Çarşısı Cinayeti ile Yusufçuk Yusuf'ta çeltik ve pamuk tarlalarını anımsatır; nitekim endüstriyel tarıma geçilmiştir. Kırsal dönüşümün dinamiklerini betimleyen tarımsal metalaşma sürecinde ekonominin yasaları üretim ilişkilerini kusursuz bir şekilde belirlemektedir. Gelişen tarımsal kapitalizm sürecinde ekolojik mülksüzleşmenin artmasıyla, kâr hırsına uygun politik bir yapı örgütlenirken, eşitsizleştirici toplumsal dönüşüm en yoğun etkileriyle sürer. Toplumsal eşitsizliklerin yaygınlığı karşısında yoksulların kolektif başarısızlığına inat insanlık onurunu temsil eden Arzuhalci Ali, Peder Casy ve Demirci Mustafa gibi kişilikleri ise adalet arayan ve haksızlıklara boyun eğmeyen roman kahramanları olarak değerlendirmek gerekir.

Sonuç olarak roman kendisini yeniden inşa eden bir tür özelliğiyle sosyolojik bir olgu olmasının yanında içi içe geçmiş toplumsal, bireysel gerçekleri ve sosyal problemleri işlemesinden kaynaklı kimliğiyle ekonomik-politik bir niteliğe de sahiptir. Üretim ilişkilerindeki değişimin farklı toplumlarda var ettiği sosyal problemleri görmek adına romanların kayda değer önemde olduğu aşikardır. $\mathrm{Bu}$ çerçevede çalışmaya konu yapılan romanların sosyolojik dokusu ekonomi-politik boyutlarıyla analiz edildiğinde, ileri sürülen bu tez bir kez daha doğrulanmaktadır. 


\section{KAYNAKÇA}

Aslan, Cumhur (2011). Türkiye'de politik roman: 12 Mart döneminde ideoloji ve edebiyat. Atatürk Üniversitesi Edebiyat Fakültesi Sosyal Bilimler Dergisi, 11 (47): 171-187.

Bauman, Zygmunt., Mazzeo, Riccardo (2019). Edebiyata övgü. (Akın Emre Pilgir, Çev.). İstanbul: Ayrintı Yayınları.

Bauman, Zygmunt (2018). Iskarta hayatlar. Modernite ve safraları. (Osman Yener, Çev.). İstanbul: Can Sanat Yayınları.

Connell William, Robert (2016). Toplumsal cinsiyet ve iktidar. (Cem Soydemir, Çev.). (2.basım). İstanbul: Ayrıntı Yayınları.

Eyigün, Sabri (2007). Modern ve geleneksel romanın temel farkları ve politik güdümlü romanın modern roman içindeki yeni konumu. Çukurova Üniversitesi Sosyal Bilimler Enstitüsü Dergisi, 16 (2): 261-268.

Fromm, Eric (1995). Umut devrimi. (Şemsa Yeğin, Çev.). (3.basım). İstanbul: Payel Yayınları.

Goldmann, Lucien (2005). Roman sosyolojisi. (Ayberk Erkay, Çev.) Ankara: Birleşik Yayınları.

Gürel, Burak (2019) Classes and status groups in times of great transformation: reading agrarian change in Çukurova through the lens of Yaşar Kemal. Hacettepe University Journal of Faculty of Letters, 36 (2): 209-220.

Gürsel, Nedim (2000). Yaşar Kemal. Bir geçiş dönemi romancısı. İstanbul: Everest Yayınları.

Güvenç, Bozkurt (1991). İnsan ve kültür. (5.basım). İstanbul: Remzi Yayınevi.

Hacısalihoğlu, Elif (2020). Sosyal politika, sınıf ve edebiyat: biraradalığın seyri ve yeni çalışmalar için yöntemsel sorular, sorunlar. Emek Araştırma Dergisi (GEAD), 11 (17): 227-238.

Kemal, Yaşar (1998). Demirciler çarşısı cinayeti/Akçasazın ağaları 1. (3.basım). İstanbul: Adam Yayınları.

Kemal, Yaşar (1999). Yusufçuk yusuf/Akçasazın ağaları 2. (3.basım). İstanbul: Adam Yayınları.

Kıray, Mübeccel (1999a). Toplumsal yapr toplumsal değişme. İstanbul: Bağlam Yayınları.

Kıray, Mübeccel (1999b). Seçme yazılar. İstanbul: Bağlam Yayınları.

Moran, Berna (1999). Türk romanına eleştirel bakış 2. (6.basım). İstanbul: İletişim Yayınları.

Onaran, Muzaffer (2003). Akçasaz'ın ağaları. Süha Oğuzertem (Haz.). Geçmişten geleceğe Yaşar Kemal içinde (s.157-163). İstanbul: Adam Yayınları.

Steinbeck, John (2019). Gazap üzümleri. (Belkıs Düşbudak, Çev.). (14.basım). İstanbul: Sel Yayıncilik.

Şahin, Osman (2013). Yaşar Kemal geniş bir nehrin akışı. (2.basım). İstanbul: Kaynak Yayınları.

Tharaud Barry, Charles (2017). Çukurova Yaşar Kemal edebiyatının temelleri. (Tahsin Çulhaoğlu, Çev.). İstanbul: Yapı Kredi Yayınları.

Tarde, Gabriel (2019). Monadoloji ve sosyoloji. (Özcan Doğan, Çev.). İstanbul: Doğu Batı Yayıncrlik.

Yılmaz, Mehmet (2013). Ahmet Oktay'a göre roman kahramanı. Cumhuriyet Üniversitesi Edebiyat Fakültesi Sosyal Bilimler Dergisi, 37 (1): 18-27. 


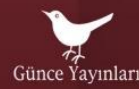

Prof. Dr. Önder Göçgün

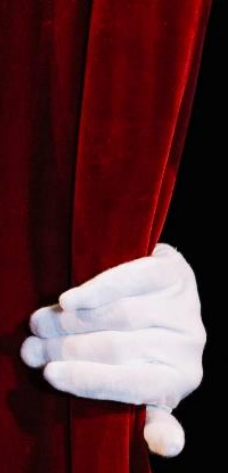

TIYYATRO DENEN HAYAT

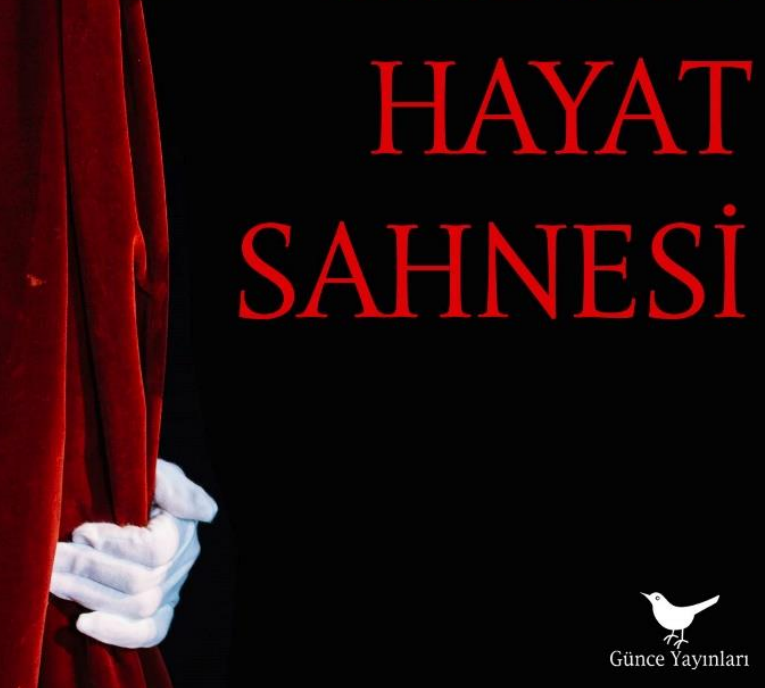

MUIIARREM DAYANC OKTAY YIVLI MACI'I BALIK MAIIMU'I BABACAN SLVIM SLERMEI
YASFMIN MUMCU BLDI் KOÇАKOĞLU NILÜLLLR ILLHAN MAKSUT YIĞITBAS SLL $\triangle M I I L \Lambda N$

\section{EDEBIYATINDA

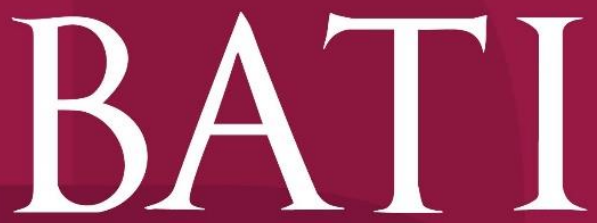 \\ EDEBIYATINDA
AKIMLAR \\ $\underset{\substack{\text { EDEBIYATINDA } \\ \text { AKIMLAR }}}{\mathrm{B} A T \mathrm{~T}}$}

editör

OKTAY YIVLI

HATICE FIRAT

YASEMIN MUMCU

OKTAY YIVLI

OĞUZHAN KARABURGU

BERNA AKYÜZ SIZGEN

NILÜFER ILHAN
ÜMMÜHAN TOPÇU

SEFA YÜCE

HANIFI ASLAN

METIN AKYÜZ

MEHMET SÜMER
YAKUP ÖZTÜRK
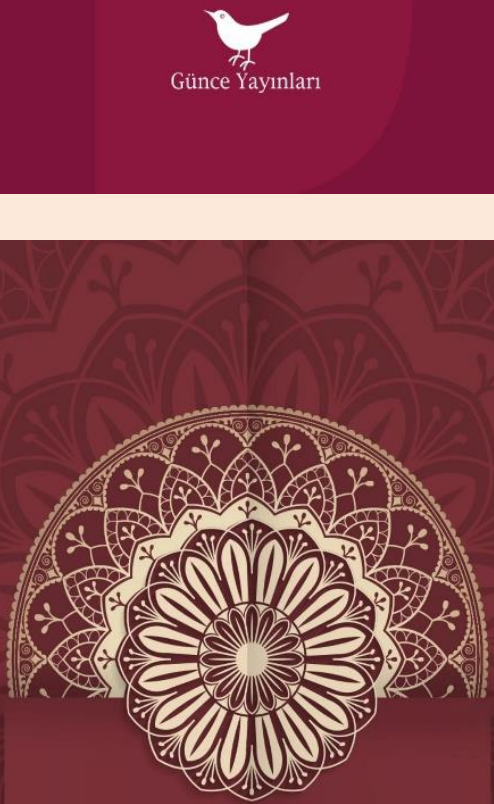

PROF. DR. ÖNDER GÖÇGÜN

$$
\begin{gathered}
\text { Türk } \\
\text { Tasavvuf } \\
\text { Siini }
\end{gathered}
$$

AÇIKLAMALI VE YORUMLU ÖRNEKLERLE 